\title{
On the term 'Jōmon' and the contribution of Russian scholars to Jōmon studies
}

\author{
Andrey V. Tabarev ${ }^{1}$, Irina S. Zhushchikhovskaya ${ }^{2}$, and Darya A. Ivanova 3 \\ 1 Division of Foreign Archaeology, Institute of Archaeology and Ethnography, Novosibirsk, RU \\ olmec@yandex.ru \\ 2 Institute of History, Archaeology and Ethnography of the Peoples of the Far East, Vladivostok, RU \\ irinaıh@mail.ru \\ 3 School of Arts and Humanities, Far Eastern Federal University, Vladivostok, RU \\ nightliro@bk.ru
}

\begin{abstract}
The article is devoted to the introduction of the term 'Jömon' into Russian archaeological literature, its understanding, and the contribution of Russian scholars to Jomon studies starting from the late 20th century. The recognition of the term and its use had some peculiarities which were caused not only by the language barrier and political events in the far eastern region, but mostly by the specifics of the archaeological investigations in the Russian Far East and the priority of research focused first on the Ainu origin, and then on the Palaeolithic rather on the nature of the Neolithic. The rise of the interest in Jömon grew in the late 1960s and early 1970s with the discoveries of initial pottery with Final Pleistocene dates in Japan and Russia (Lower and Middle Amur Region). During the 1980s and 1990s this trend was realized in a series of publications, international conferences, and the first joint Russian-Japanese archaeological projects. The current stage is illustrated by the institualization of several research centres of Jömon studies in Russia (Novosibirsk, Vladivostok), by a high level of international cooperation, and by a wide range of research topics, including chronological, technological, ritual and other aspects of the Jömon period.
\end{abstract}

KEY WORDS - Jōmon; Neolithic; Far East; pottery; technology; periodization; cooperation

\section{O terminu 'Jōmon' in prispevku ruskih znanstvenikov $k$ študijam kulture Jōmon}

IZVLEČEK - Članek je posvečen vpeljavi in razumevanju termina 'Jōmon'v ruski arheološki literaturi ter prispevku ruskih znanstvenikov k študijam te kulture od konca 20. stoletja. Prepoznavanje tega strokovnega izraza in njegove uporabe je imelo nekaj posebnosti, ki so jih povzročile tako jezikovne pregrade kot politični dogodki na območju Daljnega vzhoda, predvsem pa posebnosti arheoloških raziskav na ruskem Daljnem vzhodu in prioritete raziskav, ki so se usmerile predvsem v izvor ljudstva Ainu ter v paleolitske študije in manj v naravo neolitika. Interes za Jōmon se je povečal šele ob koncu 60. in v zgodnjih 70. letih prejšnjega stoletja z odkritjem najstareǰ̌e lončenine iz obdobja finalnega pleistocena na Japonskem in v Rusiji (spodnja in srednja regija Amur). V 80. in 90. letih prejšnjega stoletja se je ta interes pokazal v seriji publikacij, mednarodnih srečanj in v prvih združenih rusko-japonskih arheoloških projektih. Sedanjo stopnjo razvoja pa ponazarja več raziskovalnih središč posvečenih študijam kulture Jōmon v Rusiji (Novosibirsk, Vladivostok), pa tudi višji nivo mednarodnih sodelovanj in širši razpon raziskovalnih tem, ki vključujejo kronologijo, tehnologijo, rituale in druge vidike obdobja kulture Jōmon.

KLJUČNE BESEDE - Jōmon; neolitik; Daljni Vzhod; lončenina; tehnologija; periodizacija; sodelovanje 


\section{Introduction}

It is considered that American zoologist Edward Sylvester Morse was a key figure at the beginning of Jōmon studies. In 1877 he initiated the pioneering excavations at Oomori shell mound, and coined the term 'twisted cord-marked pottery' in his publications (Morse 1877; 1879). In turn, it was Shirai Mitsutaro who for first translated 'cord-marked pottery' as 'Jōmon pottery' (Jōmon-doki - 縄紋土器) in 1886 (Shirai 1886) 1 .

It should be also underlined that in Japanese archaeological literature the term 'Jomon' up to the end of 1920s had no systematic character, and was mostly used to describe the style of pottery rather than to define the archaeological period. In fact, the term Neolithic was in even wider use. There were also other definitions in English versions of Japanese texts, such as 'earlier stone age' with subdivisions of 'lower earlier stone age' and 'upper earlier stone age' (Matsumoto 1921.58-59). Only with the development of new approaches to the classification of the ceramic materials and chronology presented in the works of Sugao Yamanouchi in late 1920s and early 1930s did 'Jōmon' get the status of a period with its Earliest, Early, Middle, Late and Latest phases.

Almost at the same time - at the beginning of 1930s - the term 'Jōmon' began to appear in European archaeological literature. For example, in France the introduction of 'Jōmon' (style Jōmon-shiki) was done by Japanese archaeologist Jiujiro Nakaya, who published several papers about $\operatorname{dog} \bar{u}$ figurines, pottery and the peculiarities of the Japanese Neolithic ( $\mathrm{Na}$ kaya $1930 a ; 1930 b)^{2}$.

Despite the immediate geographical proximity and intensive archaeological surveys in the regions of the Russian Far East (Lower Amur, Maritime Region, Sakhalin) at the end of $19^{\text {th }}$ and beginning of the $20^{\text {th }}$ centuries, the archaeological interest of Russian researchers in the territory of the Japanese archipelago did not immediately acquire a systematic format and the adaptation of the Japanese terminology. The situation with the term 'Jōmon' - its intro- duction to the Russian archaeological literature, its understanding and interpretation - is one such illustrative examples.

With high probability the first Russian scientist to get acquainted with Jomon archaeological materials in Japan was Alexander V. Grigor'ev. He ended up in Yokohama in 1879 with a Russian geographical maritime expedition and decided to stay in Japan for scientific research for almost a year. Among the rich collections he presented to the Russian Geographical Society in 1880-81 was a collection of Jōmon artefacts ("ornamented pottery and stone tools from Japanese Kökkenmödding") gathered during his trips to Tokyo, Yokohama and Hakodate (Dudarec 2006).

Other early notes on the archaeological antiquities of Japan were published in 1884 by the outstanding scientist, zoologist and archaeologist Ivan S. Polyakov. Sent by the Academy of Sciences to the Far East in 1881, he made successful excavations on Sakhalin and in Primorye, after which he made a trip to Japan. While in Japan for eight months (1882-1883) he examined the materials of Oomori shell mound3. In his report, Polyakov used such terms as 'stone age', 'pre-historical inhabitants', and 'primitive inhabitants'. He was not only one of the first researchers in Russian historiography to make a description of the remains of the Jomon material culture, but also tried to consider them in the context of the connection with the ancient cultures of Sakhalin and Primorye (Polyakov 1884).

In the following years, a series of articles and books by leading orientalists, anthropologists and ethnographers of the late $19^{\text {th }}$ and early $20^{\text {th }}$ centuries were published, in which questions of the ancient history of the Japanese archipelago were addressed to some extent. It should be noted that in most cases the prehistory of Japan was considered at this time through the lens of historical sources or ethnographic works dedicated to the ancient population of the Japanese Islands - the Ainu (Anuchin 1904; Bogdanovich 1905; Pozdneev 1909; Shternberg 19294). The appearance and acceptance of the term 'Jomon'

1 'Cord-marked' was initially translated into 'Sakumon doki' ( 索紋土器) by Ryokichi Yatabe.

2 The stay of Nakaya in Paris in 1929-1932 and multiple meetings with the leaders of French archaeological and anthropological science is vividly described in an article by Laurent Nespoulous (2014).

3 Just five years after the pioneering excavation of the site by Morse.

4 This is the enlarged version of the report presented by L. Shternberg at the Third Pan-Pacific Science Congress in Tokyo in 1926. In his article in 1929 he published four pieces of "...ornamented clay fragments, found by A. V. Grigor'ev in Japan between Yokohama and Tokyo near Oomori Lake" (Sternberg 1929.345), which definitely belong to Jōmon. So, it is possible that Grigor'ev was visiting the site (Oomori Shell Mound) explored by Morse two years after the excavations. 
took place only 10 years later, but in any case, Russian scholars of the early period demonstrated high competence in the current literature and a clear understanding of the Neolithic nature of the archaeological materials from the Japanese shell mounds.

\section{Acceptance and initial use of the term 'Jōmon'}

Taking into consideration the political situation in the Far East before II World War, and control of Japan over the southern part of Sakhalin and Kuril Islands, we should definitely mention the high levels of activity of Japanese archaeologists in these territories. The first field surveys took place in 1889, $1900-1904$, then in 1920th and in early $1930^{\text {th }}(\mathrm{Va}$ silevski 2008). There are many publications with the description of the discovered and, in some cases, excavated sites, and shell mounds with the interpretation of the materials and comparisons with data on Hokkaido. The term 'Jomon' appeared in these publications as early as in 1937 in the title of an article by Nobuo Ito called "The Jómon pottery excavated on Sakhalin" (Yoshizaki, Ohnuki 1963.158).

The early to mid-1930s are of greater interest for our topic - this time was marked by several expeditions of Russian archaeologists in the far eastern territories. One such expedition took place in the eastern part of Sakhalin in 1935, where Alexander M. Zolotarev visited the series of locations near Nogliki village, and according to the stone and pottery artefacts found there described them as "Neolithic sites of exceptional quality" (Zolotarev 1936.273). Another expedition was organized and conducted by one of the key figures in our story, Alexei P. Okladnikov, along the Lower Amur between Khabarovsk and Nikholaevsk (about $1000 \mathrm{~km}$ in total). One of the primary goals of this expedition was the quest for Neolithic sites. In his short report about archaeological works in 1935 Okladnikov wrote about discovery of 135 Neolithic sites which enabled the first periodization of the Neolithic for the Lower Amur Region. This included three stages, and giving the characteristics of the first Okladnikov wrote that "... it is close by some attributes of pottery of the most ancient Neolithic sites of Japan ("proto-Ainu stratum" in shell mounds in Northern Japan) ..." (Okladnikov 1936.276). The term 'Jomon' is not in the text, but the cited phrase is a direct indication of its use as the archaeological analogy.

Over the next few years, Okladnikov consistently developed the concept of the 'Amur Neolithic culture', and presented its developed version at a special session on ethnogenesis in 19405. The report was devoted to the Neolithic of Siberia and Russian Far East, and talked about Amur Region. Okladnikov put a special focus on the peculiarities of pottery: "...suddenly rich, curvilinear ornamentation, related, on the one hand, to Ainu and Maori ornaments, and, from the other, to the Neolithic sites of China (Yangshao culture) and Japanese Islands (Joemon 6 culture) - "ribbon" ornamentation with typical "net-mark", spirals and meander..." (Okladnikov 1941.12). This is one of the first, if not the first, utilization of this term in the Russian archaeological literature, on that took place, as we mentioned above, almost 10 years later than in the European literature.

Obviously, Okladnikov was very interested in such inter-regional comparisons and in the Stone Age archaeology of the Japanese Islands as a whole. In 1946, right after the Second World War, he published a special paper "Towards the most ancient population of the Japanese Islands and Its culture". The references for this article contain more than 100 titles of books and various types of publications 7 in Russian, Japanese, English, German, and French, devoted to all aspects of the ancient history and archaeology of Japan. This list contains pioneering works by Edward S. Morse, Gordon. N. Munro, and Heinrich P. von Siebold, along with publications from Japanese archaeologists on the excavations of shell mounds in different parts of the Japanese Islands between the 1880s and 1920s, and the first publications of Japanese archaeologists about Jōmon materials in European languages. Starting in 1934 Okladnikov worked in Leningrad (St. Petersburg) at the Institute of Material Culture, and had full access to its rich library of foreign books and periodicals.

In fact, this is the first fundamental Russian work not only about the Neolithic but about the whole prehistory of Japan, including the Stone Age, Paleometal and Early Middle Ages. As for the Neolithic,

5 May 28-29th, 1940, Moscow.

6 The exact spelling in the text is 'Joemon' instead of 'Jōmon', which confirms the still unsettled status of the term.

7 In one of the footnotes Okladnikov emphasizes that the whole "... list of references for this work was lost during the war. The main part of the sources on the on the raised issues was re-compiled with the participation of $N$. A. Beregovaya ..." (Okladnikov 1946.29). This means that the work on the article started before the war (before 1941), and none of the foreign references is dated later than 1939 . 
Alexey P. Okladnikov demonstrated outstanding competence in current research and all important aspects of material culture: types of settlements, construction of dwellings, shell mounds, bone and stone tools, burials and ritual items. He paid special attention to a number of local pottery styles - including Entō and Katsusaka - and analysed in detail the dynamics of ornamentation. To describe the peculiarities of the earliest types of ornamentation he used terms such as 'rope and textile' and 'mat-marked'. The word 'Jōmon' appears in his text as 'culture of rope pottery (Jōmon-culture)' (Okladnikov 1946.18) and as one of the ornamentation types - 'Ujō-Jōmon' (spruce needles) (Ibid. 21). Using a wide range of archaeological analogies Okladnikov demonstrated the wide 'Far Eastern', and even wider 'Pacific', approach to the peculiarities of Japanese materials. The only weakness of this article is the absence of illustrations, which may be explained by technical issues or, by some political limitations and the conditions of the post-war relationship with Japan.

At the moment we have not been able to fully trace the situation with the use of the term 'Jomon' between 1946 and 1953, and this will require some additional bibliographic searches. But, in any case, it is clear that in the very late 1940s the literature about Jōmon was analysed by Mikhail A. Vorob'ev, who graduated as an orientalist from Leningrad University in 1949 and became a doctoral student of Okladnikov at the Institute of Material Culture. In 1953 Mikhail V. Vorob'ev defended his dissertation "Stone Age of the Japanese Sea Countries" (Vorob'ev 1953), regarding the Jomon as the 'Neolithic period' in the history of the Japanese Islands 8 . This dissertation became the basis for the monograph "Ancient Japan" that he published five years later (Vorob'ev 1958). This book is accompanied by a rich album of photos and illustrations of Jōmon pottery and stone tools.

1953 is a very significant milestone in our story this year is the beginning of the works of the special Far Eastern Archaeological Expedition under the leadership of Okladnikov9. This research not only resulted in a series of field works and excavations of archaeological sites with a wide chronological scale, from the Paleolithic to the Middle Ages, but also in the establishment of local archaeological centres and communities in Vladivostok, Khabarovsk and Yuzhno-Sakhalinsk.

During 1950s the term 'Jomon' was used by Russian archaeologists working in the Far East in a number of publications in the context of comparisons of types of settlements, stone tools and design of Neolithic pottery. For example, Rima V. Chubarova (Kozyreva), who conducted excavations on Sakhalin Island in 1955 and the Kuril Islands in 1956, compared the design of bone tools with the analogies in Early Jōmon (with clarification in parentheses 'Early Neolithic') (Chubarova 1957.70, 75), and noted a clear resemblance of the Neolithic pottery on Iturup Island with the pottery of Late Jōmon period on Hokkaido (Chubarova 1960.132-138) ${ }^{10}$.

In 1957 the leading archaeological journal, Soviet Archaeology, published a brief translation of an article by the Japanese archaeologist Nomio Egami, "Past and Present of Archaeology in Japan"11, with an overview of the most significant achievements of Japanese archaeology, including the subdivision of the Jomon period into five stages, the discovery of pre-Jōmon sites, and monumental complexes (stone circles and megaliths). According to N. Egami these finds may be regarded in the context of ancient contacts between Japanese Islands and Siberia (Egami 1957). This translation reflects the main result in Jōmon studies of the 1940s and 1950s - the transition from an understanding of this term as the specific design on the pottery, or style of pottery, to one of the periods of the Stone Age on the Japanese Islands.

The other important result of the 1950s was the appearance of a new direction of the interest among Russian archaeologists in the Stone Age in Japan, the pre-Jōmon and Palaeolithic periods. The discovery of Palaeolithic artefacts at Iwajuku site on Honshu Island in 1948-1949 opened a new era in Japanese archaeology and attracted the attention of the archaeologists from all over the world. Analysing the literature on the pre-Jomon complexes in Kanto region (Central Honshu) and on Hokkaido, Okladnikov wrote about them having the highest significance for far eastern archaeology, and compared the lithic and obsidian artefacts with the Paleolithic materials

8 He did not use the word 'Jōmon' in the abstract of the dissertation.

9 He managed it until his death in 1981.

10 In particular, she used the book of Gerard J. Groot "The Prehistory of Japan" (Groot 1931). Okladnikov also mentioned this book several times along with the work of Jonathan E. Kidder (Kidder 1957) as the most useful and complete collections of data on Japanese archaeology.

11 Original article: Egami N. 1956. Past and Present of Archaeology in Japan. The Oriental Economist XXIV(544): 82-83. 
in Southeast Asia (Vietnam, Indonesia) and the continental part of Eurasia (Mongolia, China, Amur Region) (Okladnikov, Goreglyad 1958.250).

Among the important events of the 1950s we would also note the first visit of Okladnikov to Japan with a presentation at the International Symposium on the History of Eastern and Western Cultural Contacts organized by UNESCO in Tokyo in November, 1957. During this three weeks long trip he had the chance to observe rich collection of archaeological artefacts in Tokyo University. In a short report about his trip to Japan he wrote: "Our attention was drawn to recently found sites of the culture which existed on the Japanese Islands about 6000 to 5000 BC. We found many similarities with the finds done by the Soviet archaeologists in Primorye. This suggests that ancient inhabitants of our Far East also took part in the peopling of the Japanese Islands..." (Okladnikov 1958.217).

\section{Jōmon studies in the context of archaeological and ethnographical research during the $1960 \mathrm{~s}$ and 1970s}

The next twenty years in the history of Jōmon studies in Russia were marked by the activities of both archaeologists and ethnographers. The ethnographers were continuing the investigations of ethnohistory of North East and East Asia started in late 1950s, and the origin of the modern Japanese population was one of the research's focuses. For example, a number of publications were devoted to the Ainu and the sequence of Jomon and Ainu populations in different regions of the Japanese Islands (e.g., Arutyunov 1960; 1961) ${ }^{\mathbf{1 2}}$.

At the beginning of 1960s Okladnikov moved from Leningrad to Novosibirsk (Western Siberia) and took an active part in the formation of the humanities at the new scientific centre. In 1966 a specialized research institute that united all the humanities, including archaeology, was established13. With this event archaeological research in Siberia and the Russian Far East received a new impetus and was dis- tinguished by the impressive scale of survey and excavation projects. A series of such projects were realized at the Neolithic sites in the Maritime Region, Lower and Middle Amur Regions, on Sakhalin and Kuril Islands by specialists from Novosibirsk, Vladivostok, Khabarovsk and Yuzhno-Sakhalinsk.

The rapid growth of materials required their analysis and interpretation using data from neighbouring territories. Therefore, there was an increase in interest in publications by Japanese authors and in direct contacts between the specialists from Russia and Japan to discuss common problems. For example, Russian archaeologists (Okladnikov14, Ruslan S. Vasil'evskij) took part in VIII International Congress of Anthropological and Ethnological Sciences (Tokyo and Kyoto, 1968), where they had the chance to observe archaeological collections and establish contacts with the leading Japanese archaeologists.

It should be underlined that the 1960s were marked by very important archaeological discoveries on the Japanese Islands - and, first of all, by the finds and dating of early pottery in such caves as Kamikuroiwa and Fukui (Ikawa 1964). Carbon dating of these complexes demonstrated the unexpected antiquity (13 000-12 $000 \mathrm{BP}$ ) of first ceramic traditions, and raised the question of whether to revise the lower chronological limits of Jomon to the Final Pleistocene time.

In 1970 the book "Siberia and Its Neighbours in Antiquity" was published in Novosibirsk with articles of Russian and American archaeologists, including on the Paleolithic and Early Neolithic sites on the Japanese Archipelago (Larichev 1970), accompanied by detailed lists of radiocarbon determinations for the Initial, Early, Middle, Late and Final periods of the Jōmon 15 .

A series of international conferences took place in Russia during 1970s - such as the International Symposium on Beringia (Khabarovsk, 1973); "Correlation of Ancient Cultures of Siberia and Neighboring Territories of the Pacific Basin" (Novosi-

12 Sergey A. Arutyunov travelled to Japan in 1960 as part of the special agreement between the Institute of Ethnography, Moscow and Tokyo University. During this two-month journey he visited Tokyo, Yokohama, Sendai, Kyoto, Osaka, Nara, and Hokkaido Island. In addition to intensive ethnographical studies he also met with archaeologists, visited sites, and made some valuable observations about the nature of the Paleolithic and Jōmon periods.

13 Currently the Institute of Archaeology and Ethnography, Siberian Branch, Russian Academy of Sciences.

14 Okladnikov made a presentation "The Neolithic of Lower Amur and Its relation to the Neolithic cultures of the other Asian regions".

15 Special article in Russian based on the publications of 1962-1968 by Richard E. Morlan, Chester S. Chard, Fumiko Ikawa, and by a number of Japanese archaeologists. 
birsk, 1975), and, in particular, the $14^{\text {th }}$ Pacific Science Congress (Khabarovsk, 1979), which brought together scientists from 46 countries. The Japanese delegation was one of the biggest (124 people), including a group of archaeologists headed by Chosuke Serizawa. After the intensive contacts that occurred during this event, Okladnikov invited Japanese archaeologists to Novosibirsk, where they got access to the collections and continued the discussion on a wide range of research topics related to the Stone Age of the North East Asia and methods of direct cooperation.

Among the scientific publications of this period the first dissertation in Russian devoted to the Jomon is of exceptional importance. It was prepared by Chan $\mathrm{Su} \mathrm{Bu}$ and had the title "Late Jōmon of Hokkaido" (Chan Su Bu 1977). He also published several articles on the Jōmon including a special investigation on the origin and implementation of the term ' $\mathrm{J} \overline{\mathrm{o}}$ mon' in Japanese archaeology (Chan Su Bu 1975)16. Various aspects of the Jomon were also analysed in the publications (articles and books) of the other authors from Moscow, Novosibirsk, Vladivostok and Yuzhno-Sakhalinsk - such as "Culture of Ancient Japan" (Iofan 1974), "Far Past of the Maritime Region and Amur Region" (Okladnikov, Derevyanko 1973), "Ancient Cultures of the Pacific North" (Vasil'evskij 1973), "Stone Age Cultures of Northern Japan" (Vasil'evskij et al. 1982)17, and so on.

In all these publications Jomon is interpreted as a Neolithic 'culture' of the Japanese Islands consisting of several periods and dated in the frame of 8000 to $2500 \mathrm{BP}$. While the materials of the Jommon culture were widely used in a comparative context with regard to the regions of the Russian Far East, the characteristics of various periods of Jōmon and its local diversity within the Japanese Archipelago were rarely specifically considered. The finds of earliest pottery (12 000 to $10000 \mathrm{BP})$ were recognized as 'Mesolithic' rather than Neolithic (Jōmon). To a large extent, this was also due to the fact that great interest of Siberian researchers in the 1960s and 1970s was associated with the Paleolithic period and the earliest manifestations of this in North East Asia (Siberia, Mongolia, Far East).

This view changed only after the dating of similar findings of early pottery in the Lower and Middle Amur Regions during the 1980s and 1990s.

\section{New topics and trends of the 1980s and 1990s}

A number of archaeological sites known since the initial surveys near Khabarovsk in late 1920s and early 1960s became the subject of a special project from the mid-1970s up to the 1990s. At the initial stage of research archaeological materials (stone assemblages) were interpreted as the 'Osipovka Mesolithic culture'. After the discovery of early ceramic fragments (in 1975 and 1980) and their carbon dating (12 960 \pm 120 BP) (Okladnikov, Medvedev 1983) it became clear that technology of pottery-making appeared in the Lower Amur Region almost at the same time as on the Japanese Islands. According to this Osipovka culture (by analogy with the Jōmon periodization) was relegated to a new stage - 'Initial Neolithic' (13 000-10 000 BP).

Subsequent discoveries of early pottery in the other regions of the Russian Far East and Trans-Baikal Region along with the analogical finds in South and Eastern China confirmed the validity of this division, and opened a wide discussion on the various aspects of this phenomenon - the function of early pottery, reasons of its origin in the context of hunters-gatherers and fishers, the independent or diffusional character of the origin, etc.

The detailed analysis of the technological characteristics of early pottery in the Far Eastern region is one of the significant contributions of Russian archaeologists to this discussion. This was effectively demonstrated in a series of publications by Irina $S$. Zhushchikhovskaya after direct observations of Jōmon collections in Tokyo and Kyoto in the mid1990s (e.g., Zhushchikhovskaya 1997). One of the main tasks facing researchers into the origin of technologies for making ceramic containers is to determine the likely raw material base and the recipe for preparing the moulding masses. It was found that the Japanese Islands within the Incipient Jomon and partially Initial Jōmon are characterized by a focus on the use of natural clay raw materials without special additives and impurities. For the Initial Jomon, there is the occasional use of compounding moulding masses with an artificial admixture of grass organic matter. The recipe technology of the early potters of Japan differed from the technology of the mainland regions of the South of the Far East, the Korean Peninsula, and Northern China, where the oldest ceramics were made from moulding masses

16 Recently the authors of this article returned to the topic and published more details on the first studies of shell mounds and discovery of Jomon-type pottery in Japan in the late $19^{\text {th }}$-early $20^{\text {th }}$ centuries (Tabarev, Ivanova 2018).

17 The monograph was based on the Japanese literature and results of research trips on Hokkaido in the late 1970s. 
with a 'clay + grass organic' composition. At an early stage of making ceramics, the quality of raw materials and moulding mass would have largely determined the method of designing clay containers.

Incipient Jōmon pottery in Japan is characterized by the technology of 'patchwork' moulding, or slab construction. There is evidence of the existence, along with the 'patchwork' sequence, of a moulding technology close to the ring sequence. It should be especially noted that there are no traces of the use of templates or form models for the manufacture of vessels on the most ancient ceramics of Japan. Another feature associated with the moulding process is the moulding of the bottom part of the vessels. For the earliest pottery of the archipelago, the leading trend is the absence of a structurally separated flattened section of the bottom, as the known examples are dominated by models of a rounded and conical bottom. In contrast to this, materials from other areas of the East Asian area of early ceramics (Southern Far East) have characteristic features of the technology of forming flat-bottomed containers using templates (hard, semi-soft-basket or rope).

From a technological perspective, it is the characteristics of the formulation of moulding masses and the features of moulding that most emphatically argue for the independent development of ceramic technology on the Japanese Islands and in the mainland regions of East Asia. At the same time, the signs of surface treatment operations and firing of clay products reflect the general technical and technological level of the initial stages of formation of pottery skills, and of their universal character. For the most ancient ceramics of Japan and most of the early ceramic complexes of the South of the Far East, and China are characterized by a lack of skills in surface treatment. According to the results of special analyses and its external characteristics, the ancient ceramics were fired in primitive conditions, in an open fire, at low temperatures from $550-600^{\circ} \mathrm{C}$.

The quest for the earliest pottery in the Maritime Region was in the focus of the first multiyear joint Russian-Japanese archaeological expedition organized by Tohoku Fukushi University (Sendai) and the Institute of History, Archaeology and Ethnography of the People of the Far East (Vladivostok) which started in 1991-92. During this project fragments of early pot- tery were discovered at the Ustinovka III Site (Kononenko 2001). According to ${ }^{14} \mathrm{C}$-dating their age is about $9300 \mathrm{BP} 18$. This remains the earliest manifestation of ceramic production in the Maritime Region.

When considering the 1990s it is also necessary to mention the beginning of a multiyear study on the exploration and distribution of volcanic glass (obsidian) in the Far Eastern region on the basis of geochemical analysis. On the Japanese Islands the obsidian was used as early as the initial stage of the peopling of the territory in the Upper Paleolithic, at 35000 to $33000 \mathrm{BP}$, and continued during all periods of the Jōmon (Kuzmin et al. 1999), which is one of the best illustrations of the intensity and directions of the contacts with regard to the Japanese Islands and adjacent territories 19 . Another example of a multi-disciplinary approach used in the 1990s is the collecting and summarizing of the database on ${ }^{14} \mathrm{C}$-dating of the Stone Age sites in the Far Eastern regions with special focus on the sites with earliest pottery (Kuzmin 1998).

\section{Current stage and interim conclusions}

The 2000s have been characterized by many advances in the organization of research, and in the international cooperation which fosters the Jomon studies by Russian archaeologists. Three points are of particular importance here, the new structure of scientific funding, new approach to the organization of research teams, and new format of the international collaboration.

Since the end of 1990s several Russian national scientific foundations ${ }^{20}$ have been developing various types of support for research (including for all the humanities) in the form of grants. This has created new possibilities for archaeologists to focus on regions, materials and problems which were not available under the previous system.

A series of such three-year projects, for example, were successfully realized over the last 15 years and are currently being conducted by specialists of a new division in the Institute of Archaeology and Ethnography, Novosibirsk (Division of Foreign Archaeology). This work has examined such topics as $\operatorname{dog} \bar{u}$ figurines and their Pacific analogies (Solov'eva et al. 2010), Jōmon pottery and its role in ritual activity

$189305 \pm 31 \mathrm{BP}$. This date was mentioned in several publications (e.g., Kononenko 2001.46).

19 The most significant contribution to the development of this topic has been made by Yaroslav V. Kuzmin. To see the enlarged list of references one could check his numerous publications in English language journals (e.g., Kuzmin 2019; Kuzmin, Shackley 2007). 20 The Russian Foundation for Basic Researches, Russian Foundation for Humanities, and Russian Science Foundation. 
(Tabarev 2017), the evolution of Jōmon settlement system and local types of Jōmon dwelling constructions (Tabarev et al. 2015), Jōmon burials and burial practices (Ivanova et al. 2013), the phenomenon of Jōmon megalithic complexes (Nesterkina et al. 2017; Tabarev et al. 2017), etc. Within these projects a number of agreements with Japanese Universities and research centres were signed which made possible the exchange of students and specialists, participation in the excavations in Japan, regular joint symposiums, and joint publications.

Some aspects of Jömon have also been successfully developed in Yuzhno-Sakhalinsk (Grishhenko 2011; Vasilevskij 2003), Vladivostok (Zhushchikhovskaya 2005; Zhushchikhovskaya, Danilova 2008), and St. Petersburg (Yanshina 2019).

In 2005,28 years after the first, the second dissertation in Russian on the Jōmon ( $\operatorname{dog} \bar{u}$ figurines) was defended by Elena A. Solov'eva (2005), and the third (about the Middle Jomon) by Darya A. Ivanova in 2018 (Ivanova 2018) 21.

A characteristic feature of publications in the 2000s is the attention to detail, to materials of separate sites (Ivanova, Tabarev 2018), and to specific features within the territory of the sites (caches, dwellings, pits), to local styles of pottery or adornments (Zhushchikhovskaya 2015), and to the difference between coastal and inland Jōmon sites.

As example of such interest is the morphological and technological analysis of Lower and Upper Entō pottery styles based on the collections of Ookubo site in The National Museum of Japanese History. In Japanese archaeology, these styles are known as one of the main indicators of cultural traditions at the Early and Middle Jōmon periods in the northern part of Honshu Island. These styles, along with their originality, show signs of continuity in the development of pottery among the ancient population of Northern Honshu. It is possible to assume a common cultural basis among the population of this region of the Japanese Islands. Changes in morphological standards are gradual and evolutionary. The most significant changes are in the ornamentation of ceramics (techniques, compositional principles, motifs, etc.), which mainly determines the visual recognition of the Lower and Upper Entō styles. These changes are a local manifestation of general trends in the dynamics of ornamental traditions of the Early and Middle Jōmon of Honshu. It is in the Middle Jōmon that the local variety of ceramic styles is most clearly expressed. In particular, the specificity of the Upper Entō style consists in the development of techniques and compositional principles that mimic three-dimensional rope structures (knots, loops, etc.) (Zhushchikhovskaya 2007; 2015).

From 2003 to 2007 Kokugakuin University (Tokyo) and Far Eastern State University (Vladivostok) implemented a joint project in the Maritime Region focused on the Early Neolithic and initial evidence of pottery-making, with the excavation of several sites in the inland (Osinovka, Gorbatka III) and coastal (Ustinovka III) zones. Some results of this research along with a series of AMS-dates were published in a joint paper in 2007 (Kunikita et al. 2007). A number of small-scale Russian-Japanese projects were also realized during early 2000s by archaeologists from Vladivostok, Khabarovsk and Yuzhno-Sakhalinsk.

Another type of international cooperation took place during the project "Neolithization and Modernization: Landscape History on East Asia Inland Seas" organized by the Research Institute for Humanity and Nature, Japan (RIHN, Kyoto) from 2007 to 2012. In this project Russia was represented by a group of specialists from Vladivostok and Novosibirsk. In addition to intensive comparative research into the Neolithic in the Russian Far East and Jomon on the Japanese Islands, the Russians got a unique chance to attend a series of international conferences in Japan and visit a wide range of museums and archaeological centres with collections of Jōmon materials (Hokkaido, Honshu, Kyusyu, Okinawa), which were never before available to Russian specialists. In 2008 a Russian group also organized an international archaeological symposium in Vladivostok which was devoted to the $100^{\text {th }}$ anniversary of Okladnikov and brought together experts in Neolithic (Jōmon) studies from Russia, Japan, Europe and the United States (Popov, Uchiyama 2008).

An extremely useful role in the growing cooperation between Russia and Japanese archaeologists is played

21 According to the current Russian system there are two types of dissertations, the lower level, so-called Candidate, and a high level, Doctorate. So far, all dissertations focused directly on Jōmon materials in Russian (Chan Su Bu 1977; Solov'eva 2005; Ivanova 2018) are of the Candidate type. All of them with some time intervals were defended at the Institute of Archaeology and Ethnography, Novosibirsk. In addition, there are several Doctorate and Candidate dissertations devoted to the archaeology of Far Eastern regions with reference to Jōmon materials - Hokkaido (Lavrov 1984), Kuril Islands (Golubev 1972) and Sakhalin (Grishhenko 2009; Vasilevskij 2003) - which were also defended in Novosibirsk. 
by a network of international conferences, such as SEAA (Society for East Asian Archaeology), CHAGS (Conference on Hunting and Gathering Societies), WAC (World Archaeological Congress), and IPPI (Indo-Pacific Prehistory Association). As an example of a new forum that is already recognized by Japanese and European archaeological societies is the "Pacific Archaeology" symposium hosted since 2018 by Far Eastern Federal University, Vladivostok.

Jōmon studies in Russian archaeology are thus growing rapidly, and the growing number of publications in English and other foreign languages on this topic confirm this. Speaking of some of the intermediate results we would like to emphasize several important points. Undoubtedly is was Okladnikov who played one of the key roles in the introduction of the term 'Jōmon' to the Russian archaeological literature, being highly interested himself in this topic and directing the interest of his students during his scientific career both while in Leningrad (St. Petersburg) and Siberia (Novosibirsk). It is thanks to his efforts that 'Jōmon' did not remain at the status of a book-study, term but was developed into a broad research subject with permanent contact and collaboration with Japanese colleagues, joint projects and excavations.

Since the first works of Lev Shternberg (1929) and Okladnikov (1940), the Japanese Neolithic (Jōmon), in spite of its visual peculiarities, was viewed by the Russian scientists from the widest possible historical perspective within the cultural process in the Far Eastern and Pacific regions.

The initial understanding of term 'Jōmon' as a specific type of decoration on the pottery or style of pottery was elaborated during the 1960s and 1970 s to the 'Jomon culture' as one of the Neolithic cultures in the Far East. This was quite consistent with the practice of Russian archaeology at that time to distinguish local and regional archaeological cultures based on the unity of the territory, chronology, and material culture.

In the 2000s this position has been significantly rethought. The New Jommon chronology (14 000 - 2500 $\mathrm{BP})$, its duration (more than 11000 years), and significant local differences in archaeological materials in various areas of the Japanese Islands, came into conflict with the traditional understanding of the 'archaeological culture' in Russian science. As a result, the current position about the Jomon in the Russian archaeological literature implies the status of a 'Jomon epoch' (with the Neolithic type of life and economy) divided into five, or, depending on the territory, six 'periods'. The term 'culture' is used in such contexts as, for example, 'material culture of the Middle Jōmon'. The term 'Jōmon culture' is also used in popular science literature and in works devoted to Japanese art and traditional crafts.

The other direction of discussion is connected with the subdivision of the Jomon epoch and with the peculiarities of Incipient and Initial Jömon periods, for which pottery does not demonstrate the 'cordmarked' design in the classical sense of this feature. Several alternative interpretations may be suggested, including the Jōmon epoch itself (Early, Middle, and Late periods) and its 'Prelude' (Incipient, Initial periods), like the transition from the Paleolithic to the Neolithic.

And, of course, one important issue is connected with wider problematic where the Jomon is considered as an example of the original scenario of the Neolithisation in the Far East - in comparison with the agricultural models on the territories of China and Korea, and from the Eurasian perspective - in format of 'Western' and 'Eastern' types of the Neolithisation. The high level of technology, settlement organization, burial rituals, monumentality, and sophisticated art indicates the dynamic evolution of Jōmon society and its ranked social structure, which allows specialists to engage in productive discussions about the possibility for the Jōmon to be considered as an 'Early Neolithic Civilization' based on highly effective environmental management.

As an additional trajectory, developed by Russian specialists, the future of Jomon studies will also be connected not only with the detailed analysis of the materials, new excavations, and comparative research between the Far Eastern and European region, but also with the understanding of Jomon phenomena as part of a specific model of the Neolithisation from a wider, Pacific, perspective. One of the recent examples of such an approach was successfully realized by a joint Russian-Japanese project in Ecuador from 2013 to 2018, including the testing of famous 'Jōmon-Valdivia hypothesis' and comparison of the various models of the transition from the Paleolithic to the Neolithic type of economy, and emergence of the pottery technologies in the Pacific basin (Kanomata et al. 2019). 
The authors are deeply grateful to their Japanese colleagues Profs. K. Akoshima, H. Kajiwara, Y. Kanomata, and T. Tsutsumi for their priceless comments on the history of the cooperation of Russian and Japanese archaeologists, to Prof. L. Nespoulous (France) for valuable information on Jōmon issues. A special debt of gratitude goes to our Russian colleagues Dr. L. B. Vishniatsky (St. Petersburg), and Dr. O. V. Yanshina (St. Petersburg) for their invaluable help with literature and archive data. The research was supported by Russian Scientific Foundation (Project \#19-18-00003 "Neolithic Civilizations of Eurasia: Jomon, Japanese Archipelago - Origin, Early Stage, Local Peculiarities").

\section{$\therefore$}

\section{References}

Anuchin D. N. 1904. Yaponiya. Antropologicheskij i etnologicheskij ocherk. Zemlevedenie IX(III). (in Russian)

Bogdanovich T. A. 1905. Ocherki iz proshlogo $i$ nastojashhego Japonii. St. Petersburg. (in Russian)

Arutyunov S. A. 1960. K ocenke roli migracij v drevnej istorii Yaponii. Sovetskaya etnografiya 1: 60-71. (in Russian)

1961. Etnograficheskaya poezdka v Yaponiyu. Sovetskaya etnografiya 3: 77-89. (in Russian)

Chan Su Bu 1975. O proiskhozhdenii termina "dzyomon". Istoriografiya i istochnikovedenie stran dal'nego Vostoka. Seriya istoricheskaya 1: 55-67. (in Russian)

1977. Pozdnij dzyomon Hokkajdo. Unpublished PhD dissertation. Novosibirsk. (in Russian)

Chubarova R. V. 1957. K istorii drevnejshego naseleniya Sahalina. Sovetskaya etnografiya 4: 60-75. (in Russian)

1960. Neoliticheskie stoyanki na o. Iturupe (Kuril'skie ostrova). Sovetskaya arheologiya 2: 128-138. (in Russian)

Dudarec G. I. 2006. Issledovatel' ajnov A. V. Grigor'ev. Izvestiya Instituta naslediya Bronislava Pilsudskogo 10: 88-101. (in Russian)

Egami N. 1957. Proshloe i nastoyashchee yaponskoj arheologii. Sovetskaya arheologiya 2: 305-307. (in Russian)

Golubev V. A. 1972. Arheologiya Kuril'skih ostrovov. Unpublished PhD dissertation. Novosibirsk. (in Russian)

Grishhenko V. A. 2009. Rannij neolit ostrova Sahalin. Unpublished PhD dissertation. Novosibirsk. (in Russian)

2011. Rannij neolit ostrova Sahalin. Sahalinskij gosudarstvennyj universitet. Juzhno-Sahalinsk. (in Russian)
Groot J. G. 1951. The Prehistory of Japan. New York.

Ikawa F. 1964. The continuity of Non-Ceramic to ceramic cultures in Japan. Arctic Anthropology 2(2): 95-119.

Iofan N. A. 1974. Kul'tura drevnej Yaponii. Nauka. Moskva. (in Russian)

Ivanova D. A. 2018. Srednij dzyomon ostrova Honsyu (5-4 tys. l. n.): obshchie harakteristiki i lokal'nye osobennosti. Unpublished $\mathrm{PhD}$ dissertation. Novosibirsk. (in Russian).

Ivanova D. A., Tabarev A. V. 2018. Pogrebal'naya praktika epohi dzyo:mon, Yaponskij arhipelag (po materialam kompleksa Kitamura). Camera Praehistorica 1: 77-93. (in Russian with English summary) https://doi.org/10.33291/26583828.2018-(1)-4

Ivanova D. A., Popov A. N., and Tabarev A. V. 2013. Vtorichnye pogrebeniya $\mathrm{v}$ glinyanyh sosudah $\mathrm{v}$ kul'ture dzyomon na territorii Severnoj Yaponii. Vestnik NGU. Seriya: Istoriya, filologiya. Arheologiya $i$ etnografiya 12(5): 146-156. (in Russian)

Kanomata Y., Marcos J., Popov A., Lazin B., and Tabarev A. 2019. New Data on Early Pottery Traditions in South America: The San Pedro complex, Ecuador. Antiquity 3(17): 1-6. https://doi.org/10.15184/aqy.2019.56

Kidder J. 1957. The Jomon Pottery of Japan. Artibus Asiae Supplementum Series 17. Artibus Asiae Publishers. Zurich. https://www.jstor.org/stable/1522589

Kononenko N. A. 2001. Ecology of cultural dynamics of archaeological sites in the Zerkalnaya River valley at the Terminal Pleistocene - Early Holocene (the Ustinovka Complex, Russian Far East). Archaeology, Ethnology and Anthropology of Eurasia 1: 40-59.

Kunikita D., Yoshida K., Miyazaki Y., Saito K., Endo A., Matsuzaki H., Ito S., Kobayashi T., Fujimoto T., Kuznetsov A. 
M., Krupyanko A. A., and Tabarev A. V. 2007. Analysis of Radiocarbon Dates of an Archaeological Site in the Russian Far East; the Marine Reservoir Effect as Seen on Charred Remains on Pottery. Nuclear Instruments and Methods in Physics Research 259(1): 467-473.

https://doi.org/10.1016/j.nimb.2007.01.307

Kuzmin Y. V. 2019. Obsidian provenance studies in the far eastern and northeastern regions of Russia and exchange networks in the prehistory of Northeast Asia. Documenta Praehistorica 46: 296-307.

https://doi.org/10.4312/dp.46.18

1998. (ed.) Radiocarbon Chronology of the Stone Age of Northeast Asia. Pacific Institute of Geography, Far Eastern Branch of Russian Academy of Sciences, Vladivostok.

Kuzmin Y. V., Glascock M. D. 2007. Two islands in the ocean: Prehistoric obsidian exchange between Sakhalin and Hokkaido, Northeast Asia. The Journal of Island and Coastal Archaeology 2(1): 99-120.

https://doi.org/10.1080/15564890701273765

Kuzmin Y. V., Tabarev A. V., Popov V. K., Glascock M. D., and Shackley M. S. 1999. Geochemical Source Analysis of Archaeological Obsidian in Primorye (Russian Far East). Current Research in the Pleistocene 16: 97-99.

Larichev V. E. 1970. Paleolit i mezolit Japonii. Sibir' i ee sosedi v drevnosti. Materialy po istorii Sibiri. Drevnjaja Sibir'. Novosibirsk: Izdatel'stvo Nauka 3: 66-108. (in Russian)

Lavrov E. L. 1984. Dokeramicheskij period Hokkajdo $i$ sopredel'nyh territorij. Unpublished $\mathrm{PhD}$ dissertation. Novosibirsk. (in Russian)

Matsumoto H. 1921. Notes on the Stone Age people of Japan. American Anthropologist 23: 50-76.

Morse E. S. 1877. Traces of Early man in Japan. Nature 17: 89 .

1879. Shell Mounds of Omori. Memoirs of the Science Department, University of Tokyo, Japan. Volume I. Part I.

Nakaya J. 1930a. Contribution à l'étude de la civilisation néolithique au Japon. Revue des Arts asiatiques VI (3): 151-167.

1930b. Figurines néolithiques du Japon. Documents 1: 25-32.

Nespoulous L. 2014. Un préhistorien japonais à Paris: Nakaya Jiujirō (1929-1932). Ebisu [Online], 51 | 2014. Online since 01 November 2014. Connection on 03 February 2020. http://journals.openedition.org/ebisu/1431
Nesterkina A. L., Solov'eva E. A., Tabarev A. V., and Ivanova D. A. 2017. The megaliths of Korea and Japan: An analysis of origins and functions. Archaeology, Ethnology and Anthropology of Eurasia 45(3): 106-114. https://doi.org/10.17746/1563-0110.2017.45.3.106-114

Okladnikov A. P. 1936. K arheologicheskim issledovaniyam v 1935 g. na Amure. Sovetskaya arheologiya 1: 275277. (in Russian)

1941. Neoliticheskie pamyatniki kak istochniki po etnografii Sibiri i Dal'nego Vostoka. Kratkie soobshcheniya instituta istorii material'noj kul'tury: 9-14. (in Russian)

1946. K voprosu o drevnejshem naselenii Yaponskih ostrovov i ego kul'ture. Sovetskaya etnografiya 4: 1133. (in Russian)

1958. Pamyatniki drevnej Yaponii. Neva 3: 217-218. (in Russian)

Okladnikov A. P., Derevyanko A. P. 1973. Dalekoe proshloe Primor'ya i Priamur'ya. Vladivostok. (in Russian)

Okladnikov A. P., Goreglyad V. N. 1958. Novye dannye o drevnejshej kul'ture kamennogo veka na severe Yaponii. Sovetskaya Arheologiya 3: 246-250. (in Russian)

Okladnikov A. P., Medvedev V. E. 1983. Issledovanie mnogoslojnogo poselenija Gasja na Nizhnem Amure. Izvestija SO AN SSSR. Serija obshhestvennyh nauk 1: 93-97. (in Russian)

Polyakov I. S. 1884. Otchet ob issledovaniyah na ostrove Sahalin, v Yuzhno-Ussurijskom krae i v Yaponii. Zapisok Imperatorskoj Akademii nauk XLVII. Supplementum V. (in Russian)

Popov A. N., Uchuyama J. 2008. (eds.) Neolit i neolitizacija bassejna Japonskogo morja: chelovek $i$ istoricheskij landshaft. Fareastern State University, Vladivostok. (in Russian with English summary)

Pozdneev D. M. 1909. Materialy po istorii Severnoj Japonii i ee otnoshenij $k$ materiku Azii $i$ Rossii. T. 1. Yokohama: Tipografija Zh. Gljuk. (in Russian)

Solov'yova E. A. 2005. Dogu: klassifikaciya i interpretaciya. Unpublished PhD dissertation. Novosibirsk. (in Russian)

Solov'eva E. A., Tabarev A. V., and Tabareva Yu. V. 2010. Dialogi s dogu: $\mathrm{k}$ probleme interpretacii antropomorfnoj plastiki tihookeanskogo bassejna. Tihookeanskaya arheologiya 18: 50-96. (in Russian)

Shirai M. 1886. Stone Arrowhead. Bulletin of the Anthropological Society 1(3): 49-51. (In Japanese). 
Shternberg L. Ya. 1929. Ajnskaya problema. Sbornik Muzeya antropologii i etnografii 8: 334-380. (in Russian)

Tabarev A. V. 2017. Dancing Shamans, Snakes and Drugs: On the Similar Motives in the Arte of Ancient Cultures of the Far East and Northern Andes. International Journal of South American Archaeology 10: 35-39.

Tabarev A. V., Ivanova D. A. 2018. Pogrebeniya, keramika, rakovinnye kuchi: iz istorii izucheniya pamyatnikov epohi Dzyo:mon, Yaponskij arhipelag. Gumanitarnye issledovaniya $v$ Vostochnoj Sibiri i na Dal'nem Vostoke 2(44): 36-42. (in Russian with English summary) https://doi.org/10.24866/1997-2857/2018-2/36-42

Tabarev A. V., Ivanova D. A., Nesterkina A. L., and Solov'eva, E. A. 2017. The Jomon megalithic tradition in Japan: Origins, features, and distribution. Archaeology, Ethnology and Anthropology of Eurasia 45(4): 45-55. https://doi.org/10.17746/1563-0110.2017.45.4.045-055

Tabarev A. V., Tabareva Yu. V., and Ivanova D. A. 2015. $\mathrm{V}$ poiskah formy: Opyt rekonstrukcii drevnejshih zhilishch kul'tury dzemon (po materialam pamyatnika Uenohara4, Kyusyu). Gumanitarnye nauki v Sibiri 22(2): 56-69. (in Russian with English summary)

Vasilevskij A. A. 2003. Kamennyj vek ostrova Sahalin. Unpublished PhD dissertation. Novosibirsk. (in Russian)

2008. Kamennyj vek ostrova Sahalin. Yuzhno-Sahalinsk: Sahalinskoe knizhnoe izdatel'stvo. (in Russian)

Vasil'evskij R. S. 1973. Drevnie kul'tury tihookeanskogo Severa. Novosibirsk. (in Russian)

Vasil'evskij R. S., Lavrov E. L., and Chan Su Bu 1982. Kul'tury kamennogo veka Severnoj Yaponii. Nauka. Novosibirsk. (in Russian)

Vorob'ev M. V. 1953. Kamennyj vek stran Yaponskogo morya. Unpublished PhD dissertation. Novosibirsk. (in Russian)
1958. Drevnyaya Yaponiya. Istoriko-arheologicheskij ocherk. Izdatel'stvo vostochnoj literatury. Moscow. (in Russian)

Yanshina 0. V. 2019. Understanding the Specific Nature of the East Asia Neolithic Transition. Documenta Praehistorica 46: 6-29. https://doi.org/ 10.4312/dp.46.1

Yoshizaki M., Ohnuki E. 1963. Prehistoric Culture in Southern Sakhalin in the Light of Japanese Research. Arctic Anthropology 1(2): 131-158.

http://www.jstor.com/stable/40315567

Zhushchikhovskaya I. S. 1997. Current Data on Late-Pleistocene/Early-Holocene Ceramics in Russian Far East. Current Research in the Pleistocene 14: 89-91.

2005. Prehistoric Pottery-Making of the Russian Far East. British Archaeological Reports IS 1434. Archaeopress. Oxford.

2007. Jomon Pottery: Cord-Imitating Decoration. Documenta Praehistorica 34: 21-30.

https://doi.org/10.4312/dp.34.3

2015. Dinamika tradicij goncharstva rannego i srednego Dzemona po materialam stilej Nizhnij Ento i Verhnij Ento). Sovremennye podhody k izucheniyu drevnej keramiki v arheologii. Moskva, 29-31 oktyabrya 2013. Institut arkheologii Rossiyskoy Akademiyi Nauk. Moskva: 186-201. (In Russian)

Zhushchikhovskaya I. S., Danilova 0. 2008. Spiral Patterns on the Neolithic Pottery of East Asia and the Far East. Documenta Praehistorica 35: 20-32.

https://doi.org/10.4312/dp.35.16

Zolotarev A. M. 1936. Noglikovskaya neoliticheskaya stoyanka (Vostochnyj Sahalin). Sovetskaya arheologiya 1: 273-274. (in Russian) 